\title{
Age and growth of the Argentine hake Merluccius hubbsi Marini, 1933 in the Brazilian South-Southeast Region during 1996-2001
}

\author{
André M. Vaz-dos-Santos* and Carmen Lúcia D. B. Rossi-Wongtschowski**
}

This is the first detailed study on the age and growth of the Argentine hake Merluccius hubbsi in Brazilian waters. A total of 3,651 specimens obtained from surveys and sampling landings using trawlers and long-lines in the South-Southeast Region $\left(21^{\circ} \mathrm{S}\right.$ to $\left.34^{\circ} \mathrm{S}\right)$ between 1996 and 2001 were analyzed. Readings of sliced and burned otoliths were conducted on 686 individuals (397 females, 129 males and 160 young - sex not identified), identifying opaque and translucent zones. Marginal increment and edge type percentage methods were used for validation, resulting in one ring per year, formed during summer-autumn. Fish with no more than eight rings and six years of age were found, the two first rings after the core being formed during the first year. Back-calculation methods were applied to length/age data and the parameters of von Bertalanffy's growth model were fitted based on average length per ring. The value of maximum theoretical length varied between $470.27 \mathrm{~mm}$ and $807.40 \mathrm{~mm}$; growth coefficient varied from 0.1657 to 0.3555 year $^{-1}$ and the theoretical age at length zero between -1.2846 and -0.4552 years. Growth of females and males differed significantly. The techniques applied and the results obtained are discussed and compared with studies on hake conducted in Uruguay and Argentina, providing important information for the management of the species in Brazil, where it presents clear signs of overexploitation.

Este é o primeiro estudo detalhado sobre a idade e o crescimento da merluza Merluccius hubbsi no Brasil. Foram analisados 3.651 espécimes obtidos em cruzeiros de pesquisa e provenientes das frotas de arrasto e espinhel de fundo da região SudesteSul do Brasil $\left(21^{\circ} \mathrm{S}\right.$ a $\left.34^{\circ} \mathrm{S}\right)$ entre 1996 e 2001 . Leituras de secções transversais de otólitos (corte, polimento e queima) foram realizadas para 686 indivíduos (397 fêmeas, 129 machos e 160 jovens com sexo não identificado), identificando-se zonas opacas e translúcidas. Foram calculados o incremento marginal e a porcentagem do tipo de borda, no tempo, para validação, resultando em um anel por ano, formado durante o verão-outono. Foram obtidos peixes com até oito anéis e seis anos de idade, sendo que os dois anéis depois do núcleo se formam durante o primeiro ano de vida. Foram aplicados métodos de retrocálculo aos dados de comprimento na idade e os parâmetros do modelo de von Bertalanffy foram estimados. O valor do comprimento máximo teórico variou entre $470,27 \mathrm{~mm}$ e $807,40 \mathrm{~mm}$; a taxa de crescimento variou de 0,1657 a 0,3555 ano $^{-1}$ e a idade teórica de comprimento zero entre $-1,2846$ e - $-0,4552$ anos. O crescimento de fêmeas e machos difere significativamente. As técnicas aplicadas e os resultados obtidos foram discutidos, sendo comparados com estudos realizados no Uruguai e na Argentina e provendo informação importante para a gestão da espécie no Brasil, onde a merluza apresenta claros sinais de sobrepesca.

Key words: Merluccius hubbsi, Growth parameters, Otolith, Age structure, South-Southeastern region of Brazil.

\section{Introduction}

The Argentine hake, Merluccius hubbsi Marini 1933 (Gadiformes: Merlucciidae), is a demersal-pelagic species distributed in the West Atlantic from $21^{\circ} \mathrm{S}$ to $55^{\circ} \mathrm{S}$ (Figueiredo \& Menezes, 1978; Menezes et al., 2003; Cousseau \& Perrotta, 2004). Due to its great economic importance, it has been widely studied in Uruguay and Argentina, where Angelescu et al. (1958) focused for the first time on its life history pattern. As with other hakes elsewhere in the world (Alheit \& Pitcher,
1995), M. hubbsi is of great commercial importance in these two countries (Csirke, 1987), where many studies have been published about its reproductive habits and behavior (from Ciechomski, 1967 to Macchi et al., 2006), feeding habits (Angelescu \& Fuster de Plaza, 1965; Angelescu \& Cousseau, 1969; Angelescu \& Prenski, 1987; Prenski \& Bezzi, 1991; Prenski \& Angelescu, 1993; Ruiz \& Fondacaro, 1997; Sánchez \& García de La Rosa, 1999), identification of stocks (Bezzi \& Perrotta, 1983; Perrotta \& Sánchez, 1992; Gutiérrez et al., 1995; Norbis et al., 1999; Sardella \& Timi, 2004); general biology

\footnotetext{
*Instituto Oceanográfico da Universidade de São Paulo - IOUSP. Laboratório de Ictiofauna. Praça do Oceanográfico, 191 sala 103A, 05508120 São Paulo, SP, Brazil / Universidade Santa Cecília - UNISANTA. amvaz@usp.br; andre@unisanta.br

** Instituto Oceanográfico da Universidade de São Paulo - IOUSP. cwongski@usp.br
} 
and management (Rey et al., 1996; Rey \& Arena, 1999; Aubone et al., 2000; Aubone et al., 2004; Bezzi et al., 2004; Sabatini, 2004) and biomass estimations (Arena et al., 1987; Rey et al., 1987; Bezzi \& Ibáñez, 2003). Many growth studies have been undertaken by Otero (1977), Gaggiotti \& Renzi (1990), Renzi \& Pérez (1992), Villarino \& Giussi (1992), Giussi et al. (1994), Torres et al. (1996), Norbis et al. (1999), Renzi et al. (1999), Lorenzo (2003) and Brown et al. (2004).

On the Brazilian coast $M$. hubbsi is found between $21^{\circ} \mathrm{S}$ and $34^{\circ} \mathrm{S}$, at depths between $30 \mathrm{~m}$ and $700 \mathrm{~m}$. It was traditionally fished by trawlers in small quantities prior to 2001, when commercial fleets expanded their fishing grounds to the shelf break and upper continental slope (Perez et al., 2003; Vazdos-Santos, 2005; Perez \& Pezzutto, 2006), starting to fish greater quantities of the species (Vaz-dos-Santos \& RossiWongtschowski, 2005). Since them, commercial landings of the Argentine hake in Brazil have grown by 197\% (1996-2004) (Valentini \& Pezzutto, 2006). Moreover, bottom trawl surveys conducted in the area have revealed high M. hubbsi concentrations in Brazilian waters (Haimovici et al., 2005), closely related to the seasonal oceanographic characteristics of the region (Rossi-Wongtschowski \& Paes, 1993; Seeliger et al., 1998; Rossi-Wongtschowski \& Madureira, 2006).

Despite its importance for fisheries, the biology of $M$. hubbsi has only been studied in the past by Haimovici et al. (1993), who focused on aspects of its reproductive and feeding habits in Southern Brazilian waters. After them, the following new studies have added to knowledge of the species: Vaz-dos-Santos (2002) on its growth, Vaz-dos-Santos \& RossiWongtschowski (2005) on population dynamics and catches, Vaz-dos-Santos et al. (2005) on length of first gonadal maturation, Honji et al. (2006) on ovarian development, Perez \& Pezzutto (2006) on the exploitation of demersal species on the continental slope and Vaz-dos-Santos et al. (2006) on the management of its shared stock with Uruguay and Argentina. The above and Haimovici et al. (2006) study on the high numbers of juveniles taken in commercial landings have sought to call attention to the overexploitation of M. hubbsi in Brazil. According to this consensus, adequate management of the species and increased knowledge of the growth parameters of Brazilian stocks are urgently necessary.

Growth studies are the first step to a knowledge of population dynamics (Csirke, 1980) and permit the identification of stocks and catch structures (based on age composition), the longevity, mortality estimates and stock assessments whether for analytical considerations (Sparre \& Venema, 1998) or ecological approaches (Gasalla \& Rossi-Wongtschowski, 2004; Walters \& Martell, 2004).

Weatherley \& Gill's (1987) review shows that growth studies may be conducted in four ways: mark-recapture, cultivation, length-frequency analysis and ring interpretation of scales, otoliths, vertebrae and other structures. Considering that as: (i) Jones (1974 apud Podestá, 1990) postulated it is impossible to adopt mark-recapture procedures for hake, (ii) the longevity of this group exceeds twenty years (Alheit \& Pitcher, 1995) and (iii) in Brazil there had been no commercial landing series of biological data, ring interpretation constitutes the only mean of investigation of the growth of the Argentine hake. This is an advantage, since it is the most accurate method and provides the best results (Bagenal \& Tesch, 1978; FAO, 1981; King, 1995). In addition, the fact that Argentinian and Uruguayan hake growth studies have also been based on otolith analysis is well established, thus permitting comparisons.

The goal of this study was to provide a growth parameter estimate for M. hubbsi off the South-Southeast of Brazil and undertake the first detailed investigation related into its growth, time and patterns of ring formation, age validation techniques, age determination, application of back-calculation techniques and von Bertalanffy growth estimates.

\section{Material and Methods}

During the Brazilian National Program for the evaluation of the Economic Exclusive Zone Resources (REVIZEE Program), seasonal surveys and commercial landing samplings were conducted in the South-Southeast Brazilian region from 1996 to 2001, using bottom-trawls, mid-water trawls and bottom long-lines (Fig. 1). Commercial landing samples from bottom trawls and bottom long-line fishing gear were also used.

Total length $(\mathrm{Lt})$ of each specimen was measured to the nearest millimeter and total weight $(\mathrm{Wt})$ was recorded to the nearest gram. The sex was attributed on the basis of the macroscopic scale of Vazzoler (1996) and the maturity stages in accordance with Honji et al. (2006). Fish with incipient gonadal development, making the registration of sex difficult, were named as not identified (NI). The pair of otolith sagitta was removed from the auditive capsules, washed and dried (FAO, 1981; Secor et al., 1991). Length, height and weight

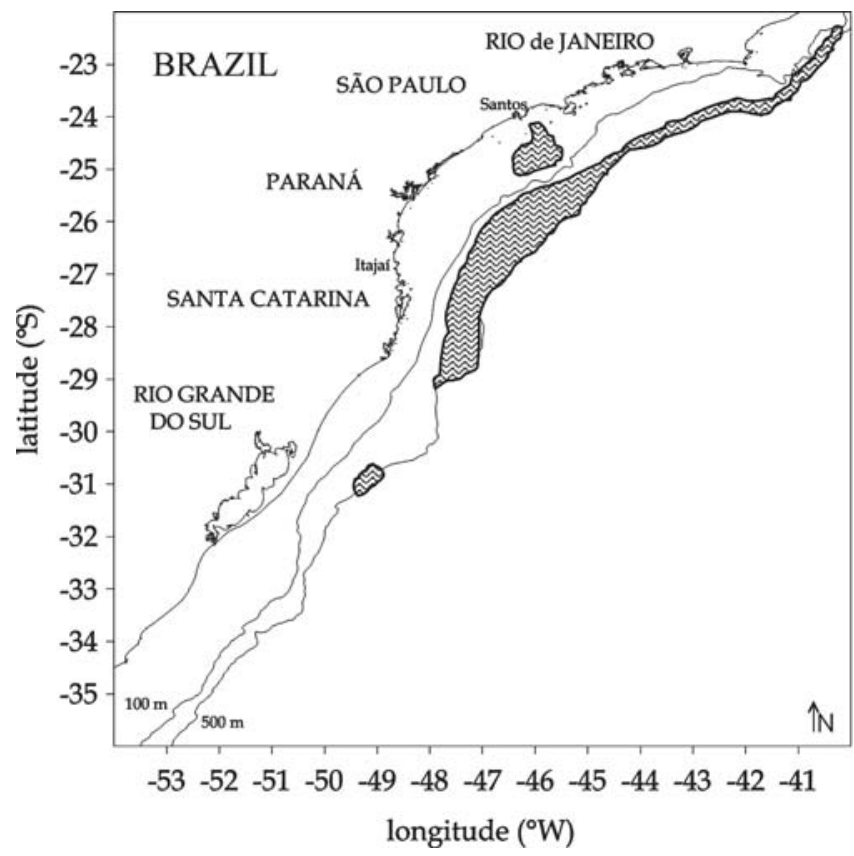

Fig. 1. Study area showing the location of Merluccius hubbsi samples collected during 1996-2001. 
measurements (Lo, Ho and Wo, respectively) were taken from whole otoliths (Fig. 2). A paired t-test using otolith measurements was performed to ascertain left-right differences $(\alpha=$ $0.05 \%)$. Regression and residual analyses were conducted to describe otolith growth in relation to body growth and the relationship between otolith measurements, for males and females and pooled data. Covariance analysis was used to identify differences among regressions. All statistical procedures took Zar (1999) in account.

For otolith readings, sub-sampling was adopted in the attempt to obtain at least twenty hake of each sex and $30 \mathrm{~mm}$ length class. The otoliths were processed in accordance with FAO (1981), Secor et al. (1991) and Otero (1977); the last specific for $M$. hubbsi, who adopted transversal sections and burning (Christensen, 1964; Polat \& Gumü $\left.{ }^{\circ}, 1996\right)$ as the best technique for ring visualization. Otoliths greater than $15 \mathrm{~mm}$ were sectioned directly on a metallographic sharper. Otolith smaller than $15 \mathrm{~mm}$ were mounted in nautical resin before cutting, ensuring the integrity of the structure.

Transversal otolith sections were examined twice under a stereomicroscope applying reflected light by one reader, without giving any information about size, sex of the fish, area or sampling period (Bagenal \& Tesch, 1978). The analysis was undertaken based on ICSEAF (1983) and Renzi \& Pérez (1992) who established a criterion for ring interpretation adopted by other authors (Torres et al., 1996; Renzi et al., 1999; Norbis et al., 1999; Lorenzo, 2003). A translucent band (TR - a narrow region of clear aspect, dark when burned and related to lower growth rates, intercalated with an opaque band - $\mathrm{OP}-$ a wide region related to faster growth rates) was considered as one ring. The otolith radius (Ro) and ring radius ( $\mathrm{Ra}$ ) were measured from the nucleus to the edge of the otolith (Fig. 3). Special attention was given to the two rings formed during the first year, named respectively the first and second demersal rings (after Buratti, 2003). The character (translucent or opaque) of the otolith edge was noted. When no agreement among number of rings, edge pattern and ring measurements was detected (more than $5 \%$ of variability), a third reading was taken. After that, if any doubt persisted, the otoliths were excluded from the analysis. All otoliths (whole and sliced) are preserved in the collection of the Laboratório de Ictiofauna, Instituto Oceanográfico da Universidade de São Paulo (from MEHU 000001/1 until MEHU 570812/3).

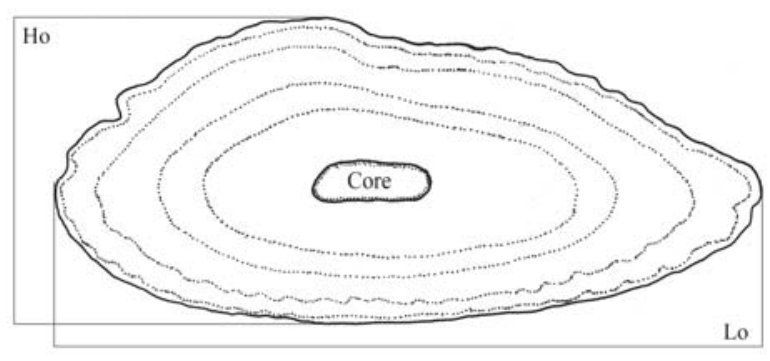

Fig. 2. Merluccius hubbsi: scheme of a whole right otolith showing core and length (Lo) and height (Ho) measurements.
The reliability of ring measurements was assessed by a plot of constancy based on the analysis of the measurements of each ring-group, undertaken with all the data and each sex. Differences between otolith ring averages were tested applying variance analysis, after data normality and homocedasticity had been checked (Zar, 1999).

Since one of the most important steps in aging studies is the validation, the establishment of timing and periodicity of ring formation (Beamish \& McFarlane, 1983), marginal increment and percentage of edge pattern were calculated with data from the samples over time. Marginal increments were calculated using the equation proposed by Mio (1961):

$$
\mathrm{MI}=(\mathrm{Ro}-\mathrm{Rmax}) / \mathrm{Ro}
$$

where Ro is the otolith radius and Rmax is the outermost ring mark. This methodology, despite the availability of other formulations (Matsuura, 1961; Cadwallader, 1978; Tanaka et al., 1981; Hyndes et al., 1992), is widely applied in growth studies (Cotrina, 1977; Newberger \& Houde, 1995; Bernardes, 2002; Amezcua et al., 2006), though not for M. hubbsi. The average marginal increment values were compared as between seasons by variance analysis (Zar, 1999).

The back-calculation technique permits (i) the estimation of fish length at the time of ring formation, generating lengths at poorly represented ages, (ii) the magnification of quantities of length data, (iii) the corroboration of ring readings and (iv) greater accuracy for the estimation of parameters. The Fraser-Lee method (Bagenal \& Tesch, 1978) has been applied traditionally as well as Francis's (1990) body and structure proportional hypothesis (BPH and $\mathrm{SPH}$, respectively) and Campana (1990). The Fraser-Lee method uses the linear coefficient (a) derived from the regression between otolith radius and total length of the fish (Ro $\mathrm{Lt}$ ) in the equation:

$$
\mathrm{La}=\mathrm{a}+[(\mathrm{Lt}-\mathrm{a}) / \mathrm{Ro}] \cdot \mathrm{Ra}
$$

where $\mathrm{La}$ is the total length at age $\mathrm{a}, \mathrm{Lt}$ is the total length of the fish, Ro is the otolith radius and Ra is the radius of the otolith at age a. Francis's BPH hypothesis (1990) also uses the regression Ro x Lt to calculate the expected fish length in relation to its otolith radius. The correction factor (f) was calculated by dividing the observed by the expected total length and it was used to adjust the back-calculated lengths at the time of ring formation by multiplication. On the other

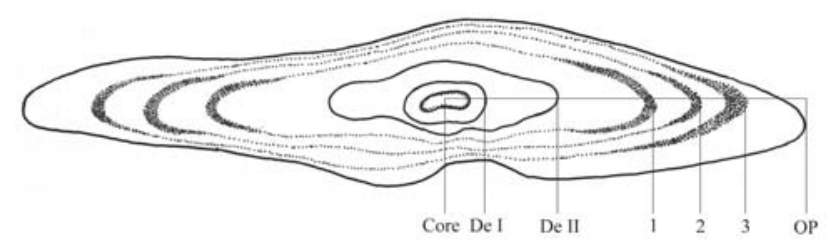

Fig. 3. Merluccius hubbsi: scheme of a sliced otolith showing core, demersal I (De I), demersal II (De II), 1 to 3 rings and opaque edge (OP). 
hand, the SPH hypothesis based on the regression Lt $x$ Ro permits the estimation of the expected otolith radius in relation to the fish's total length. Another correction factor (f') used to adjust the ring radius was calculated by dividing the observed by the expected otolith radius values.

Campana (1990) adapted Fraser-Lee's method based on the concept of the biological intercept (the starting point of the proportionality between fish length and otolith growth) using the equation:

$$
\mathrm{La}=\mathrm{Lt}+\left\{\left[(\mathrm{Ra}-\mathrm{Ro}) \cdot\left(\mathrm{Lt}-\mathrm{Lo}{ }^{\prime}\right)\right] /\left(\mathrm{Ro}-\mathrm{Ro}{ }^{\prime}\right)\right\}
$$

where $\mathrm{La}$ is the length at age $\mathrm{a}, \mathrm{Ra}$ is the radius ring at age a, Ro is the total radius of the otolith, Lt is the fish's total length, Lo' and Ro' are the biological intercept considering here the values adopted by Vaz-dos-Santos (2002) for $M$. hubbsi in Brazil as $57 \mathrm{~mm}$ and $0.52 \mathrm{~mm}$, respectively.

The von Bertalanffy growth model (VBGM) (von Bertalanffy, 1938) was fitted to age data using Solver in Microsoft Excel (Kelly et al., 1997; Bellucco et al., 2004; David et al., 2005) for both observed and back-calculated lengths at age, for males and females separately and together, using the equation:

$$
\mathrm{La}=\mathrm{L}_{\text {inf }}\left[1-\mathrm{e}^{-\mathrm{K}(\mathrm{a}-\mathrm{a})},\right]
$$

where $\mathrm{La}$ is the predicted mean length at age $\mathrm{a}, \mathrm{L}_{\text {inf }}$ is the maximum theoretical mean length, $\mathrm{K}$ is the growth coefficient and $\mathrm{a}_{0}$ is the theoretical age at length zero. Comparisons among growth parameters obtained by different methods (observed and back-calculated) were made using the growth performance index $(\phi)$ developed by Munro \& Pauly (1983):

$$
\phi=\log \mathrm{K}+2 \log \mathrm{L}_{\mathrm{inf}}
$$

The values obtained by this calculation were compared by means of a variance analysis (Zar, 1999).

\section{Results}

A total of 3,651 M. hubbsi specimens were caught during the surveys and from commercial landings between 1996 and 2001. The data were grouped in order to give a representative number and lengths for the analysis (Fig. 4). The minimum Lt was $24.00 \mathrm{~mm}$ and the maximum $647.00 \mathrm{~mm}$ (average 206.23 $\mathrm{mm}$ and median $200.00 \mathrm{~mm}$ ). By sex 1,048 females $(45.00 \mathrm{~mm}<$ $\mathrm{Lt}<647.00 \mathrm{~mm}), 809$ males $(97.00<\mathrm{Lt}<575.00 \mathrm{~mm})$ and 1,794 not identified $(24.00 \mathrm{~mm}<\mathrm{Lt}<490.00 \mathrm{~mm})$, were obtained in the samples.

The left and right otolith measurements did not present any differences ( $p>0.05$ for Lo, Ho and Wo), allowing the use of any of them. Regressions fitted and determination coefficients are presented in Table 1, for both sexes and all the fish. For all the otolith regressions analyzed, the difference between the sexes was significant $(\mathrm{p}<0.001)$. Lt, Lo and Ho were described by both linear and logarithm models. The re-

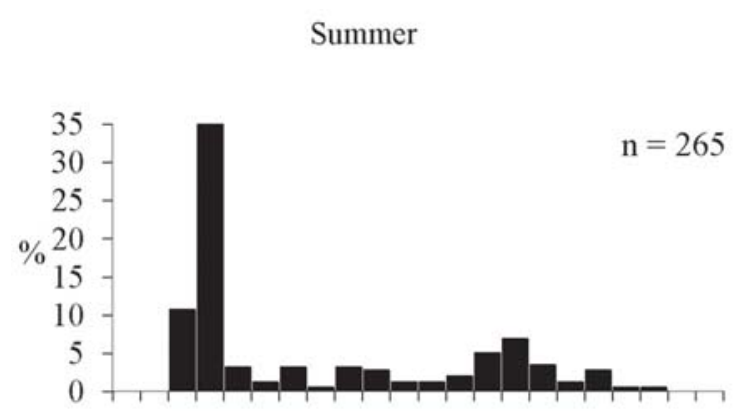

Autumn

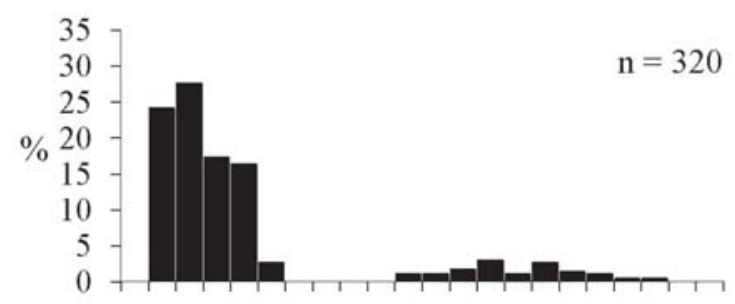

Winter
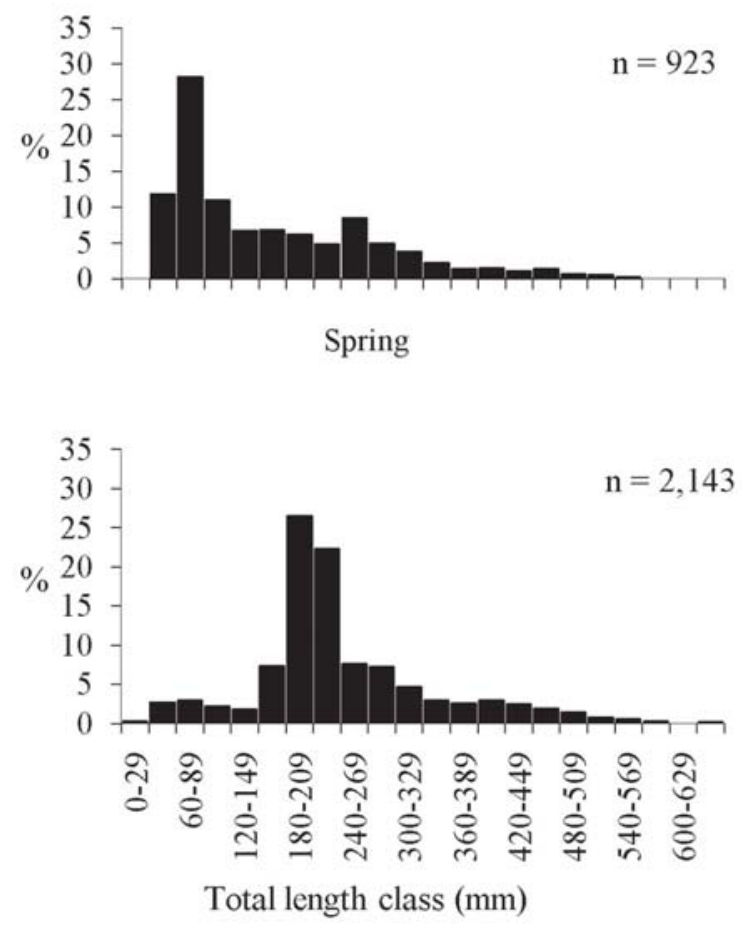

Fig. 4. Merluccius hubbsi: seasonal length class distribution obtained from surveys and commercial landings during the period 1996-2001.

lationships involving otolith weight (Wo) were best described by power regressions. Thus, the otoliths of the Brazilian $M$. hubbsi can also be used for aging studies.

A total of 705 otolith sections were examined and $70.0 \%$ of agreement was found as between the first and the second readings. After the third reading, this percentage grew to $97.3 \%$ 
Table 1. Merluccius hubbsi: parameters of the fits related to otolith measurements, determination coefficient $\left(\mathrm{r}^{2}\right)$ and sample sizes (n).

\begin{tabular}{cccccc}
\hline Model Fitted & Sex & $\mathrm{a}$ & $\mathrm{b}$ & $\mathrm{r}^{2}$ & $\mathrm{n}$ \\
\hline Lt-Lo & all fishes & 0.5693 & 0.0446 & 0.9902 & 1.036 \\
linear & Female & 0.5060 & 0.0446 & 0.9914 & 889 \\
& Male & 0.2370 & 0.0469 & 0.9849 & 614 \\
Lt-Wo & all fishes & $9.10^{-8}$ & 2.4200 & 0.9767 & 848 \\
power & Female & $9.10^{-8}$ & 2.4155 & 0.9782 & 716 \\
& Male & $5.10^{-8}$ & 2.5616 & 0.9512 & 438 \\
Lt-Ho & all fishes & -12.417 & 3.2420 & 0.9639 & 1.074 \\
logarithm & Female & -12.404 & 3.2478 & 0.9666 & 924 \\
& Male & -10.088 & 2.7345 & 0.9371 & 637 \\
Lo-Wo & all fishes & 0.0001 & 2.5409 & 0.9866 & 981 \\
power & Female & 0.0001 & 2.5360 & 0.9867 & 849 \\
& Male & 0.0001 & 2.6048 & 0.9687 & 571 \\
Lo-Ho & all fishes & -2.6629 & 3.2872 & 0.9541 & 1.126 \\
logarithm & Female & -2.6465 & 3.3066 & 0.9584 & 975 \\
& Male & -1.7326 & 2.6736 & 0.9301 & 695 \\
Ho-Wo & all fishes & 0.0007 & 2.7724 & 0.9867 & 990 \\
power & Female & 0.0007 & 2.7741 & 0.9867 & 856 \\
& Male & 0.0007 & 2.6699 & 0.97 & 573 \\
\hline
\end{tabular}

with the sub-sample (686 sections, being 397 females, 129 males and 160 young of unidentified sex remaining to the next steps). No fish was found with more than eight rings in the otoliths. Based on the criteria adopted, the first one after the core was identified as demersal I, the second as demersal II and the others were numbered from one to six. The number of fish by ring-group is presented in Table 2.

The constancy plot showed little overlap among ring measurements whether for females or males together (Fig. 5) and separately. The ANOVA applied to the average ring radius showed significant differences for the sexes analyzed together $\left(\mathrm{F}=15,185.35, \mathrm{p}<0.001, \mathrm{r}^{2}=0.9782\right)$ and separately $(\mathrm{F}=$ $12,897.71, \mathrm{p}<0.001, \mathrm{r}^{2}=0.9786$ for females and $\mathrm{F}=3,233.76, \mathrm{p}$ $<0.001, \mathrm{r}^{2}=0.9717$ for males).

The marginal increment calculated for the fish with two (Fig. 6) and three (Fig. 7) rings, which were the most frequent in the samples, showed that rings are formed annually. However, the time of the ring formation of these two groups did not match: group two presented ring formation in autumn and group three during summer. No significant differences were found in the marginal increment averages as between

Table 2. Merluccius hubbsi: specimen frequency by edge pattern and ring-group.

\begin{tabular}{cccc}
\hline Ring-group & Edge Pattern & Absolute Frequency & Total \\
\hline \multirow{2}{*}{0} & OP & 143 & 236 \\
\multirow{2}{*}{1} & TR & 93 & \\
& OP & 63 & 103 \\
2 & TR & 40 & \\
& OP & 60 & 115 \\
\multirow{2}{*}{3} & TR & 55 & \\
& OP & 76 & 155 \\
4 & TR & 79 & 64 \\
& OP & 34 & 11 \\
5 & TR & 30 & \\
& OP & 6 & 2 \\
\hline \multirow{2}{*}{6} & TR & 5 & 686 \\
\hline
\end{tabular}

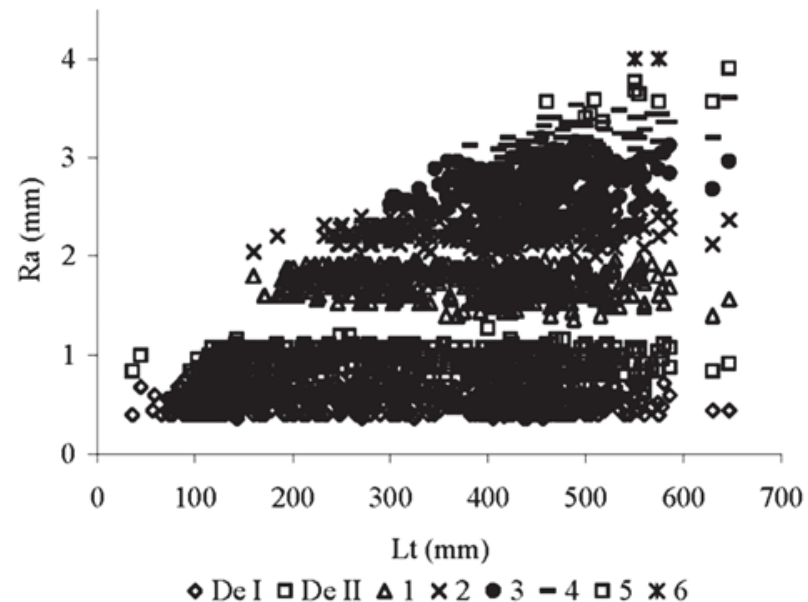

Fig. 5. Merluccius hubbsi: plot for total length ( $\mathrm{mm})$ and ring radius $(\mathrm{mm})$ showing the constancy of otolith readings.

seasons for ring-group two $(F=1.35, \mathrm{p}=0.262)$ and for ringgroup three $(\mathrm{F}=1.41, \mathrm{p}=0.241)$. It was not possible to analyze the sex data separately due to the low number of males caught. In this way, females showed the same graphic shape, illustrated in Figs. 6 and 7. Concerning the analysis of the edge pattern by season, conducted on ring-groups two and three (Fig. 8 and Fig. 9, respectively), the results showed the same aspects described for periodicity and seasonality. The highest percentages of translucent edge were found during autumn for ring-group two and during the summer for ringgroup three.

Since one year was obtained after the validation of the rings, an age-length distribution table was prepared (Table 3). For the back-calculation procedures of Fraser-Lee and the $\mathrm{BPH}$ hypothesis, power regressions between otolith radius (Ro) and total length were fitted to the data of all the fish ( $\mathrm{Lt}$ $\left.=99.7 \mathrm{Ro}^{1.2576}, \mathrm{r}^{2}=0.9536, \mathrm{p}<0.001\right)$, both females $(\mathrm{Lt}=101.26$ Ro $\left.{ }^{1.259}, \mathrm{r}^{2}=0.9603, \mathrm{p}<0.001\right)$ and males $\left(\mathrm{Lt}=102.71 \mathrm{Ro}^{1.1062}\right.$, $\left.r^{2}=0.9488, p<0.001\right)$. The regressions between total length and otolith radius were also fitted for all the fish $(\mathrm{Ro}=-5.7642$ $\left.+1.4558 \ln \mathrm{Lt}, \mathrm{r}^{2}=0.9456, \mathrm{p}<0.001\right)$, females $(\mathrm{Ro}=-5.7172+$ $\left.1.4489 \ln \mathrm{Lt}, \mathrm{r}^{2}=0.9408, \mathrm{p}<0.001\right)$ and males $(\mathrm{Ro}=-5.2744+$ $\left.1.3583 \ln \mathrm{Lt}, \mathrm{r}^{2}=0.9457, \mathrm{p}<0.001\right)$.

Observed lengths and mean back-calculated lengths at ages (Table 4) were used to fit the growth parameters of the VBGM. The maximum theoretical length varied between $470.27 \mathrm{~mm}$ and $807.40 \mathrm{~mm}$; the growth coefficient varied between 0.1657 and 0.3555 year $^{-1}$; the theoretical age at length zero varied between -1.2846 and -0.4552 years and the growth performance index continued at between 4.88 and $5.05(\mathrm{~F}=$ $\left.28.63, p=0.001, r^{2}=0.7816\right)$ (Table 5). Growth curves are shown for females (Fig. 10) and males (Fig. 11).

\section{Discussion}

This study is the first detailed growth analysis of $M$. hubbsi in Brazilian waters showing that otolith ring counting is a satisfactory method for the assessment the species age, as 


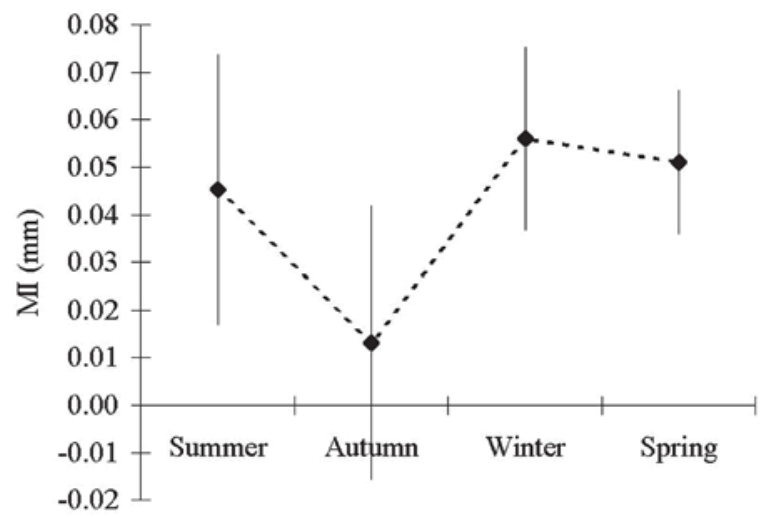

Fig. 6. Merluccius hubbsi: seasonal average marginal increment (MI, mm) and confidence limits obtained for all fish with two rings.

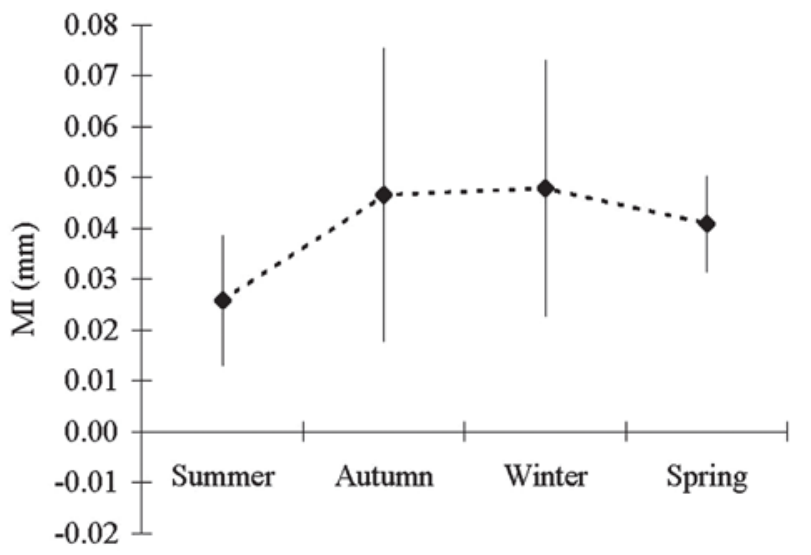

Fig. 7. Merluccius hubbsi: seasonal average marginal increment (MI, mm) and confidence limits obtained for all fish with three rings.

Table 3. Merluccius hubbsi: age-length distribution obtained from ring-counts of the otoliths.

\begin{tabular}{|c|c|c|c|c|c|c|c|c|}
\hline Total length class (mm) & 0 & 1 & 2 & 3 & 4 & 5 & 6 & Total \\
\hline \multicolumn{9}{|l|}{$0-29$} \\
\hline $30-59$ & 4 & & & & & & & 4 \\
\hline $60-89$ & 30 & & & & & & & 30 \\
\hline $90-119$ & 68 & & & & & & & 68 \\
\hline $120-149$ & 68 & & & & & & & 68 \\
\hline $150-179$ & 33 & 2 & 1 & & & & & 36 \\
\hline $180-209$ & 20 & 19 & 1 & & & & & 40 \\
\hline $210-239$ & 12 & 31 & 2 & & & & & 45 \\
\hline $240-269$ & 1 & 23 & 11 & & & & & 35 \\
\hline $270-299$ & & 17 & 23 & & & & & 40 \\
\hline $300-329$ & & 7 & 25 & 5 & & & & 37 \\
\hline $330-359$ & & 3 & 12 & 11 & & & & 26 \\
\hline $360-389$ & & 1 & 7 & 18 & 2 & & & 28 \\
\hline $390-419$ & & & 13 & 34 & 5 & & & 52 \\
\hline $420-449$ & & & 9 & 33 & 11 & & & 53 \\
\hline $450-479$ & & & 5 & 27 & 12 & 1 & & 45 \\
\hline $480-509$ & & & 3 & 10 & 12 & 4 & & 29 \\
\hline $510-539$ & & & 3 & 11 & 11 & 2 & & 27 \\
\hline $540-569$ & & & & 5 & 7 & 2 & 1 & 15 \\
\hline $570-599$ & & & & 1 & 4 & & 1 & 6 \\
\hline \multicolumn{9}{|l|}{$600-629$} \\
\hline $630-659$ & & & & & & 2 & & 2 \\
\hline Total & 236 & 103 & 115 & 155 & 64 & 11 & 2 & 686 \\
\hline
\end{tabular}

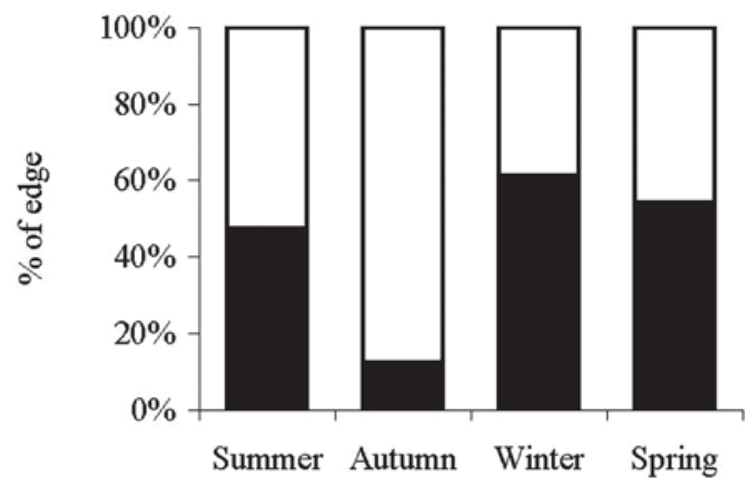

口OP $\square \mathrm{TR}$

Fig. 8. Merluccius hubbsi: seasonal frequency of opaque (OP) and translucent (TR) edges for fish otoliths with two rings.

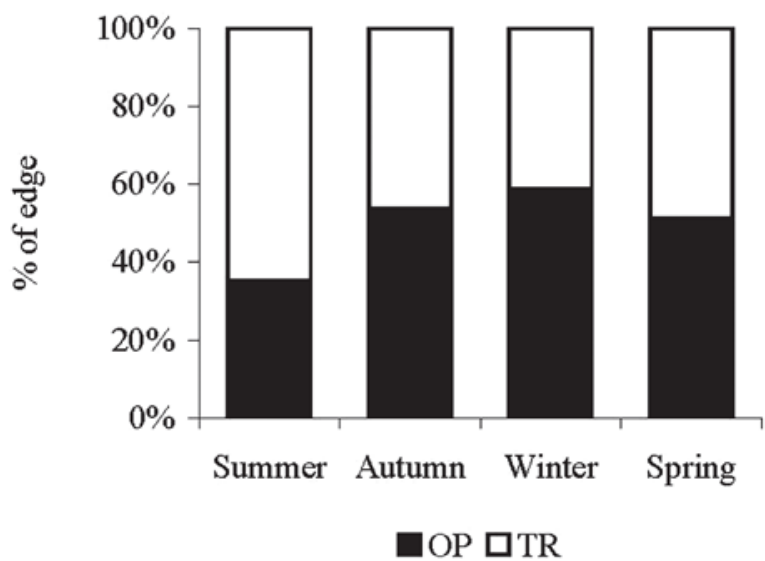

Fig. 9. Merluccius hubbsi: seasonal frequency of opaque (OP) and translucent (TR) edges for fish otoliths with three rings.

Table 4. Merluccius hubbsi: average total length at age from otolith rings and back-calculation analysis.

\begin{tabular}{|c|c|c|c|c|c|c|c|c|}
\hline \multirow{2}{*}{ Method } & \multirow{2}{*}{ Sex } & \multicolumn{7}{|c|}{ Age-group } \\
\hline & & 0 & 1 & 2 & 3 & 4 & 5 & 6 \\
\hline \multirow[t]{3}{*}{ Rings } & ishes & 131.10 & 245.00 & 340.00 & 430.30 & 483.90 & 537.00 & 562.50 \\
\hline & C & 122.70 & 245.80 & 362.10 & 435.30 & 483.90 & 540.70 & 550.00 \\
\hline & Males & 125.30 & 239.82 & 288.15 & 348.78 & 540.00 & 500.00 & 575.00 \\
\hline \multirow[t]{3}{*}{ Fraser-Lee } & All fishes & & & 335.92 & 401 & 457.86 & 513.12 & 546.80 \\
\hline & & 15 & & 344.42 & 4( & 8 & & 536.93 \\
\hline & $\mathrm{Ma}$ & 132 & 22 & 28 & 35 & 3 & 4 & 556.84 \\
\hline \multirow[t]{3}{*}{ BPH } & All fishes & 67.26 & 201.32 & 291.78 & 373. & 438.53 & 498.40 & 538.63 \\
\hline & Females & 66.73 & 203.62 & 296.75 & 376.24 & 439.27 & 502.90 & 529.91 \\
\hline & Males & 71.78 & 199.81 & 266.04 & 337. & 452.08 & 482.59 & 550.59 \\
\hline \multirow[t]{3}{*}{ SPH } & All fishes & 87.70 & 174.67 & 251.68 & 336.13 & 405.00 & 467.16 & 519.00 \\
\hline & Females & 85.94 & 171 & 252.28 & 33 & 406.12 & 473.23 & 513.40 \\
\hline & Males & 84.31 & & & & & 432.20 & 522.86 \\
\hline \multirow[t]{3}{*}{ Campana } & All fishes & 82.51 & 221.59 & 308.68 & 385 & 447. & 505.61 & 542.90 \\
\hline & & 81.60 & 225. & 314.89 & 388.2 & 447.9 & 509.54 & 533.57 \\
\hline & Males & 78.62 & 204.62 & 269.31 & 340.81 & 456.64 & 485.95 & 552.23 \\
\hline
\end{tabular}

has been done by Uruguayan and Argentinian scientists.

Relationships between otolith length, height and weight presented high values for the coefficient of determination $\left(r^{2}\right)$, indicating that otoliths represent fish growth adequately. Only Ruarte (1997) presented these relationship values for M. hubbsi from Argentina and his results were similar to those of the present study, although higher values were found in 
Table 5. Merluccius hubbsi: growth parameters and growth performance index obtained in the present study.

\begin{tabular}{lccccc}
\hline Method & Sex & $\mathrm{L}_{\text {inf }}$ & $\mathrm{K}$ & $\mathrm{a}_{0}$ & $\phi$ \\
\hline Rings & All fishes & 782.92 & 0.1991 & -0.9129 & 5.09 \\
& Females & 660.95 & 0.2871 & -0.7080 & 5.10 \\
& Males & 797.75 & 0.1523 & -1.1395 & 4.99 \\
Fraser-Lee & All fishes & 737.00 & 0.1863 & -1.2846 & 5.01 \\
& Females & 674.94 & 0.2231 & -1.2099 & 5.01 \\
& Males & 614.42 & 0.2000 & -1.2365 & 4.88 \\
BPH & All fishes & 725.51 & 0.2091 & -0.4881 & 5.04 \\
& Females & 685.82 & 0.2332 & -0.4552 & 5.04 \\
& Males & 470.27 & 0.3555 & -0.4796 & 4.90 \\
SPH & All fishes & 807.40 & 0.1657 & -0.6845 & 5.03 \\
& Females & 743.53 & 0.1924 & -0.6259 & 5.03 \\
& Males & 533.11 & 0.2667 & -0.6592 & 4.88 \\
Campana & All fishes & 697.23 & 0.2279 & -0.5854 & 5.04 \\
& Females & 656.91 & 0.2584 & -0.5415 & 5.05 \\
& Males & 474.89 & 0.3497 & -0.5320 & 4.90 \\
\hline
\end{tabular}

Brazil, associated with warmer water temperatures. The Argentine hake occurs in Brazil in the upper portion of the Brazilian Current, which is composed of Tropical Water (temperature above $20^{\circ} \mathrm{C}$ ) and the South Atlantic Central Water (SACW, $6^{\circ}-20^{\circ} \mathrm{C}$ ) (Castro et al., 2006). These temperatures are higher than those of the water masses that flows on the Argentinian continental shelf, a mixture of Malvinas (Falklands) Current with Sub-Antarctic and continental waters (Guerrero \& Piola, 1997). In this area, surface temperatures vary between $7^{\circ} \mathrm{C}$ and $8^{\circ} \mathrm{C}$ in winter and $10^{\circ} \mathrm{C}$ and $11^{\circ} \mathrm{C}$ in summer (Boltovskoy, 1981; Piola \& Rivas, 1997). Moreover, Lombarte \& Lleonart (1993) have proved higher temperatures accompany higher rates of otolith growth, especially for Gadiform fish.

Sliced otoliths are the best way to investigate the rings in the Argentine hake. Otero (1977) and Gaggiotti \& Renzi (1990) compared whole and sectioned otoliths, but since Renzi \& Pérez (1992) established a trustworthily criteria for ring-counts based on sliced otoliths, this methodology has traditionally been used for the species (Villarino \& Giussi, 1992; Giussi et al., 1994; Torres et al., 1996; Norbis et al., 1999; Renzi et al., 1999; Lorenzo, 2003).

The percentage of agreement among counts was highly satisfactory. Gaggiotti \& Renzi (1990), Renzi \& Pérez (1992), Villarino \& Giussi (1992) and Giussi et al. (1994) normally made

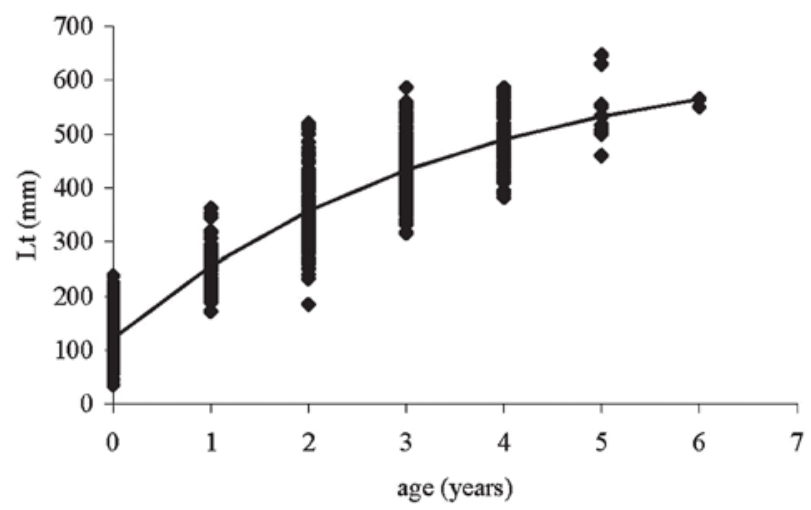

Fig. 10. Merluccius hubbsi: age-size data and growth curve fitted applying Campana back-calculated method for females. otolith analyses with two readers simultaneously, discarding those for which there was no consensus, but in none of the papers cited was the percentages of coincidence among counts presented.

This paper introduces a new classification for the ring arrangement since many authors have been referring to the rings formed during the first year as pelagic and demersal, respectively (Torres et al., 1996; Norbis et al., 1999; Lorenzo, 2003). Buratti (2003), based on otolith microstructure analysis, showed that the "pelagic ring" is formed two months after birth, when younglings migrated from the pelagic to the demersal habitat, with approximately $30 \mathrm{~mm}$ of total length. Thus, "pelagic ring" is not an appropriate designation and we have called it demersal ring I. The second is the demersal ring II, previously named demersal. The reasons for demersal ring formation are still unknown according to the most recent studies on M. hubbsi's growth (Lorenzo, 2003; Brown et al., 2004).

The constancy graph permits the analysis of a biological and a methodological aspect. In the first case, it is possible to conclude that there is no absorption or decalcification of the otoliths. In the second case, the counts presented no tendency. These present authors have found no published papers that use this kind of analysis for M. hubbsi.

In relation to the time formation of rings, the Uruguayan and Argentinian studies have all used the aspect of the edge for validation. Otero (1977) and Lorenzo (2003) verified annual ring deposition, a wide and conspicuous translucent zone. These authors also refer to a second translucent mark, not identified in the present study. Norbis et al. (1999) also observed the predominance of one translucent edge during the year. The two methods used here also showed the annual deposition of rings in otoliths, occurring during summer-autumn for $M$. hubbsi from Brazilian waters.

The variations in the average marginal increment did not differ significantly (ANOVA, $p>0.05$ ), due to the presence of fish with an opaque and translucent edge throughout the year. This variability was also found in Argentinian and Uruguayan studies. Otero (1977) determined October (spring) as the period of ring formation, disregarding secondary rings in his analysis. Gaggiotti \& Renzi (1990) found ring formation

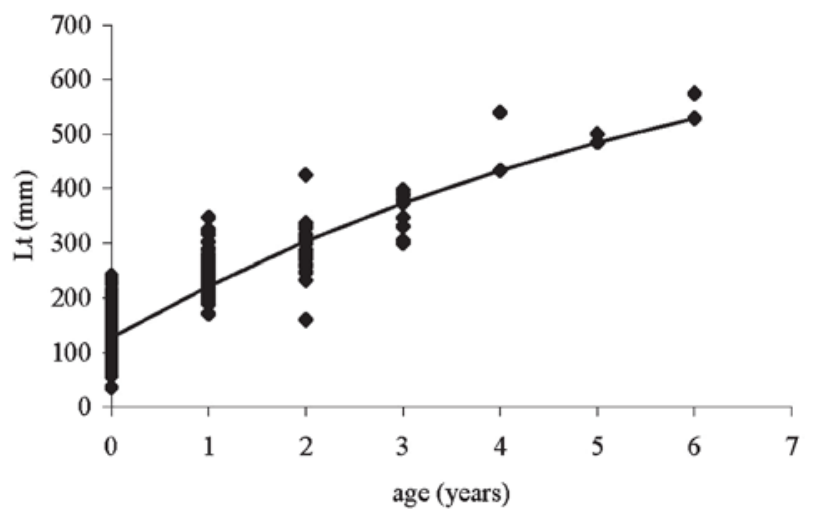

Fig. 11. Merluccius hubbsi: age-size data and growth curve fitted applying Campana back-calculated method for males. 
during the second semester. Lorenzo (2003) indicated late winter and early spring as the seasons of ring formation. However, Norbis et al. (1999) evidenced high frequencies of translucent bands in fish caught during the spring and summer with opaque bands increasing in the autumn and predominant in the winter, thus agreeing with our results.

Ring formation implies alterations in somatic growth (Bagenal \& Tesch, 1978; Weatherley \& Gill, 1987; Lombarte \& Lleonart, 1993). Reproduction and feeding modify the organism's physiology (Vazzoler, 1996; Zavala-Camin, 1996) and explain ring formation, in association with environmental conditions such as fluctuations of productivity and food availability. In Brazil, Honji et al. (2006) showed that the Argentine hake is a multiple spawning species and spawning females are caught in the Southeast-South region throughout the year. Besides, Lessa et al. (2006) recently showed that validation through marginal increments in multiple spawners is affected by the extensive period of oocyte liberation. These facts might be related to the ring formation in otoliths, it being reasonable to hypothesize that reproduction (spawning) is responsible for the time variability found in ring formation.

Concerning age structure, Argentine hake of four, five and six years of age were sporadic in the samples, males being rare. These ages were lower than those observed in Uruguay and Argentina. At the beginning of the Argentine hake fishery, Angelescu et al. (1958) identified fish of between one and seven years old. After them, reports summarizing results of surveys conducted during the later sixties and the earlier seventies record fish of between one and thirteen years old (Rojo \& Silvosa, 1969; Odemar \& Silvosa, 1971). Otero (1977) found both males and females with no more than nine years of age. Gaggiotti \& Renzi (1990) again found fish of up to thirteen years of age. Nevertheless, these studies were conducted before the establishment of the criteria for otolith ring counts in M. hubbsi established by Renzi \& Pérez (1992). So an overestimation of the age by two years as regards the interpretation of the first rings may have occurred, it being acceptable that these studies recorded fish of up to eleven years of age. After the publication of Renzi \& Pérez's (1992) criteria, Giussi et al. (1994) recorded fish of from one to ten years old. Lorenzo (2003) and Bezzi et al. (2004), giving the most recent data about age and growth of the species in Uruguay and Argentina, reported females of eleven years of age and males of eight.

All the above studies present similar mean lengths for age as this present one in Uruguayan and Argentinian waters. A tendency to a reduction in length has been detected over the years, due to overexploitation (Aubone et al., 2000; Bezzi et al., 2004). These studies also confirm that females grow bigger and live longer than males, as has also been found in Brazil. However, only earlier ages have been found in Brazil, as historical observations of commercial landings have shown that more than fifteen years ago larger and older hake were common. This fact suggests that the Argentine hake is overexploited, corroborating the same diagnosis made by Vaz-dos-Santos \& Rossi-Wongtschowski (2005) and Haimovici et al. (2006) based on the large number of juveniles (of less than $356.80 \mathrm{~mm} \mathrm{~L}_{50}$, according to Vaz-dos-Santos et al., 2005) present in the commercial landings.

Fraser-Lee's back-calculation method is based on the linearity of the relationship between otolith radius and total length, with the straight line not intersecting the origin (Bagenal \& Tesch, 1978; Campana, 1990). This fact could have led to the abandonment of the use of this methodology. However, Hile (1970) reviewed the relations between the otolith radius and the length of the fish, checking on many studies presenting non-linear fits. Particularly, Monastyrsky (1930 apud Hile, op. cit.) was one of the first authors who fitted a non-linear relationship and obtained satisfactory results. Francis (1990) also agrees that the non-linear fits may be used. Power relationships obtained between otolith radius and total length reflect the behavior of the whole otolith in the height axis, presuming that this pattern will be maintained in the transversal section. Proportional methods (BPH and SPH) had been considered initially by Whitney \& Carlander (1956) and reconsidered by Francis (1990), who recommended the application of both techniques. The difference between the two estimations results in a degree of imprecision. Campana (1990) proposed his back-calculation method as a modification of Fraser-Lee's, minimizing bias by applying the biological intercept concept, the starting-point of the otolith and fish length relationship. The main problem of this relates to the determination of the values of Lo' and Ro'. Francis (1995) had criticized it, pointing out that this assertion was only a conjecture and dependent on detailed knowledge of early growth. Brown et al. (2004) calculated Lo' and Ro' in larvae of M. hubbsi from Argentina, obtaining $2.0 \mathrm{~mm}$ and $7.7 \mathrm{~mm}$, respectively. We have considered it inappropriate to use these values for Brazilian hake, since it is better to use values calculated for the same area; so in the present study the biological intercept was adopted from the values obtained from the smallest fish ever captured in our samples, used earlier with success by Vaz-dos-Santos (2002).

Except for the Fraser-Lee method for ages zero and one, all other methods applied underestimated mean total lengths for age in relation to those calculated from ring counts. Lorenzo (2003) was the only one who used back-calculation (Campana method) for Argentine hake. According to Bagenal \& Tesch (1978), length underestimation could be related to the Lee phenomenon and may be attributed to various factors: (i) incorrect back-calculation, (ii) no random sample (larger fish advantage), (iii) natural selection (favoring younger fish) and (iv) fish mortality. The first two hypotheses can certainly be discarded because different back-calculation methods had been used to prevent model failures and a variety of fishing gear had been used for sampling. It is impossible anyway to quantify the effect the mortality rates exert on the population analyzed.

As for back-calculation functions, already commented on Material and Methods, we consider that their application gave support to ring reading and accuracy for parameter estima- 
tion. Analyzing VBGM parameter estimates and comparing them with mean lengths obtained from rings counts, attention must be draw to two points: the lowest values of $t_{0}$ may be assumed to be the closest to reality, because the fish hatch five days after fertilization (Bezzi et al., 2004); $\mathrm{L}_{\text {inf }}$ values must be close to the maximum total lengths observed. Thus the best VBGM parameter fit derive from Campana back-calculated lengths, fortunately the method that has the best biological basis and is the same as that adopted in Uruguay for M. hubbsi (Lorenzo, 2003). Attention must be given to male parameter estimations based on mean lengths obtained from ring-counts, the values of which are far too high, greatly exceeding the true ones. Besides, only growth parameters whose values for the growth coefficient $(\mathrm{K})$ of the males are higher than those for the females can be biologically acceptable.

The growth performance index takes the natural relationship between the maximum theoretical length and the growth coefficient into consideration (Munro \& Pauly, 1983) and may reflect the diet of a species (Isaac-Nahum, 1990). According to this latter author, $\phi$ values near group five (found in $M$. hubbsi) represent an active carnivorous species on a high trophic level. The results of the present study showed males already in group four (approximating to five) and females in group five. This reflects the smaller lengths attained by males, as a consequence of differential growth. In a trophic approach, males occupy lower depths than females, having other feeding ground (Angelescu \& Prenski, 1987), thus also justifying differences in $\phi$ values as between sexes. Comparing the growth parameters obtained here with those from the relevant literature after Renzi \& Pérez (1992) (Table 6) it is possible to diagnose the same situation as is described above. Older and larger specimens of $M$. hubbsi, especially females, are still present in the most recent Uruguayan and Argentinian landings and surveys (Lorenzo, 2003; Bezzi et al., 2004), reflected in the greater values of maximum theoretical mean length.

Summarizing, the growth parameters based on Campana back-calculation method obtained for $M$. hubbsi are the most adequate, being $\mathrm{L}_{\text {inf }}=656.91 \mathrm{~mm}, \mathrm{~K}=0.2584$ year $^{-1}$ and $\mathrm{t}_{0}=$ 0.5415 year for females and $\mathrm{L}_{\text {inf }}=474.89 \mathrm{~mm}, \mathrm{~K}=0.3497$ year ${ }^{1}$ and $\mathrm{t}_{0}=-0.5320$ year for males. If no sex information is available, parameters estimated for sex pooled may be used $\left(\mathrm{L}_{\mathrm{inf}}=\right.$ $697.23 \mathrm{~mm}, \mathrm{~K}=0.2279$ year $^{-1}$ and $\mathrm{t}_{0}=-0.5854$ year). The drastic reduction in the number of fish of above three years of age clear demonstrates the overexploitation of the Argentine hake in Brazil.

It seams that Brazilian M. hubbsi growth does not occur in the same way of that observed in Uruguay and Argentina, but studies that are being finished showing that Argentine hake in the South Brazilian area is a shared species between these countries.

\section{Acknowledgements}

We would like to express our gratitude to Prof. Dr. Yasunobu Matsuura (deceased), Dr. José Roberto Verani and Dr. Lisbeth Kaiserlian Cordani for their great contributions to this paper. Thanks also to the REVIZEE Program for its financial support. The contribution of Dr. Walter Norbis and Dr. María Inés Lorenzo (DINARA/Uruguay) was fundamental in their teaching and discussing of the interpretation of otoliths. Dr. Marizilda Magro was pleasant with otoliths illustrations. The librarians Mrs. Gabriela Silvoni and Mrs. Guillermina Cosulich and the scientific researchers Lic. Susana I. Bezzi, Lic. Marta Renzi and Lic. Betina Santos (INIDEP/Argentina) were all very helpful in providing references.

\section{Literature Cited}

Alheit, J. \& T. J. Pitcher. 1995. Hake: fisheries, ecology and markets. London, Chapman \& Hall, 478p.

Amezcua, F., C. Soto-Avila \& Y. Gree-Ruiz. 2006. Age, growth, and mortality of spotted rose snapper Lutjanus guttatus from the southeastern Gulf of California. Fisheries Research, 77: 293-300.

Table 6. Merluccius hubbsi: growth parameters and growth performance index obtained from the relevant literature.

\begin{tabular}{|c|c|c|c|c|c|c|c|}
\hline Study & Method & Sex & $\mathrm{L}_{\text {inf }}$ & $\mathrm{K}$ & $\mathrm{a}_{0}$ & $\phi$ & Area / Period \\
\hline \multirow{4}{*}{$\begin{array}{c}\text { Bezzi } \\
\text { et al. } \\
\text { (2004) }\end{array}$} & \multirow[t]{4}{*}{ Rings } & Females & 885.5 & 0.1883 & -0.27 & 5.17 & \multirow{4}{*}{$\begin{array}{c}\text { Argentina, } \\
\text { northern stock, } 2003 \\
\text { Argentina, } \\
\text { southern stock, } 2003\end{array}$} \\
\hline & & Males & 616.6 & 0.3960 & -0.38 & 5.18 & \\
\hline & & Females & 980.0 & 0.1458 & -0.42 & 5.15 & \\
\hline & & Males & 542.9 & 0.3852 & 0.01 & 5.06 & \\
\hline \multirow{12}{*}{$\begin{array}{l}\text { Lorenzo } \\
(2003)\end{array}$} & \multirow[t]{2}{*}{ Rings } & Females & 933.50 & 0.1610 & -0.727 & 5.15 & \\
\hline & & Males & 539.30 & 0.3630 & -0.442 & 5.02 & \multirow{3}{*}{$\begin{array}{c}\text { Uruguay, } \\
\text { Autumn, } 1994\end{array}$} \\
\hline & \multirow[t]{2}{*}{ Campana } & Females & 806.40 & 0.1790 & -0.537 & 5.07 & \\
\hline & & Males & 519.10 & 0.3200 & -0.661 & 4.94 & \\
\hline & \multirow[t]{2}{*}{ Rings } & Females & 826.80 & 0.1890 & -0.598 & 5.11 & \multirow{5}{*}{$\begin{array}{l}\text { Uruguay, } \\
\text { Spring, } 1994\end{array}$} \\
\hline & & Males & 487.40 & 0.4430 & -0.266 & 5.02 & \\
\hline & \multirow[t]{2}{*}{ Campana } & Females & 761.60 & 0.2080 & -0.344 & 5.08 & \\
\hline & & Males & 487.90 & 0.3480 & -0.345 & 4.92 & \\
\hline & \multirow[t]{2}{*}{ Rings } & Females & 889.40 & 0.1600 & -0.777 & 5.10 & \\
\hline & & Male & 509.90 & 0.3850 & -0.661 & 5.00 & \multirow{3}{*}{$\begin{array}{c}\text { Uruguay, } \\
\text { Autumn, } 1995\end{array}$} \\
\hline & \multirow{2}{*}{ Campana } & Females & 810.20 & 0.1800 & -0.493 & 5.07 & \\
\hline & & Males & 493.00 & 0.3700 & -0.380 & 4.95 & \\
\hline \multirow{4}{*}{$\begin{array}{c}\text { Giussi } \\
\text { et al. } \\
\text { (1994) }\end{array}$} & \multirow[t]{4}{*}{ Rings } & Females & 757.03 & 0.217 & -0.333 & 5.09 & \multirow{4}{*}{$\begin{array}{c}\text { Argentina, } \\
\text { Summer, 1983 } \\
\text { Argentina, } \\
\text { Winter, 1983 }\end{array}$} \\
\hline & & Males & 506.80 & 0.33 & -0.881 & 4.93 & \\
\hline & & Females & 757.67 & 0.247 & -0.525 & 5.15 & \\
\hline & & Males & 514.31 & 0.323 & -1.080 & 4.93 & \\
\hline
\end{tabular}


Angelescu, V. \& M. B. Cousseau. 1969. Alimentación de la merluza en la región del Talud Continental Argentino, época invernal (Merlucciidae, Merluccius merluccius hubbsi). Boletín del Instituto de Biología Marina, Mar del Plata, 19: 1-78.

Angelescu, V. \& M. L. Fuster de Plaza. 1965. Migraciones verticales rítmicas de la merluza del sector bonaerense (Merlucciidae, Merluccius hubbsi) y su significado ecológico. Anais da Academia Brasileira de Ciências, 37: 194-214.

Angelescu, V., F. S. Gneri \& A. Nani. 1958. La merluza del mar argentino; biología y taxonomía. Buenos Aires, Servicio de Hidrografía Naval, 225p.

Angelescu, V. \& L. B. Prenski. 1987. Ecología trófica de la merluza común del Mar Argentino (Merlucciidae, Merluccius hubbsi) Parte 2: dinámica de la alimentación analizada sobre la base de las condiciones ambientales, la estructura y las evaluaciones de los efectivos en su área de distribución. Contribución INIDEP, 561: 1-206.

Arena, G., P. Grunwaldt \& A. Fernandez. 1987. Análisis de posibles cambios en la estructura del recurso merluza en la Zona Común de Pesca Argentino-Uruguaya. Publicaciones de la Comisión Técnica Mixta del Frente Marítimo, 3: 25-36.

Aubone, A., S. I. Bezzi, G. Cañete, R. Castrucci, C. Dato, G. Irusta, A. Madirolas, M. Pérez, M. Renzi, B. Santos, M. Simonazzi \& F. Villarino. 2004. Evaluación y sugerencias de manejo del recurso merluza (Merluccius hubbsi). La situación hasta 1999. Pp. 207-235. In: Sánchez, R. \& S. I. Bezzi (Eds.). El Mar Argentino y sus recursos pesqueros. Tomo 4: Los peces marinos de interés pesquero. Caracterización biológica y evaluación del estado de explotación. Mar del Plata, INIDEP, 359p.

Aubone, A., S. I. Bezzi, R. Castrucci, C. Dato, P. Ibáñez, G. Irusta, M. Pérez, M. Renzi, B. Santos, N. Scarlato, M. Simonazzi, L. Tringali \& F. Villarino. 2000. Merluza (Merluccius hubbsi). Pp. 30-39. In: Bezzi, S. I., R. Akselman \& E. E. Boschi (Eds.). Síntesis del estado de las pesquerías marítimas argentinas y de la Cuenca del Plata. Años 1997 - 1998, con la actualización de 1999. Mar del Plata, INIDEP, 388p.

Bagenal, T. B. \& F. W. Tesch. 1978. Age and growth. Pp. 101-136. In: Bagenal, T. B. (Ed.). Methods for assessment of fish production in fresh waters. $3^{\text {rd }}$ Ed. Oxford, Blackwell Scientific Publications, 365p.

Beamish, R. J. \& G. A. McFarlane. 1983. The forgotten requirement for age validation in fisheries biology. Transactions of the American Fisheries Society, 112: 735-743.

Bellucco, A., A. Hara, E. M. Almeida \& C. L. D. B. RossiWongtschowski. 2004. Growth parameters estimates of Maurolicus stehmanni Parin \& Kobialinsky 1996 (Teleostei, Sternoptichydae) from South and Southeastern Brazilian waters. Brazilian Journal of Oceanography, 52(3/4): 195-205.

Bernardes, R. A. 2002. Age, growth and longevity of the gray triggerfish, Balistes capriscus (Tetraodontiformes: Balistidae), from the Southeastern Brazilian Coast. Scientia Marina, Barcelona, 66(2): 167-173.

von Bertalanffy, L. 1938. A quantitative theory of organic growth. Human Biology, 10: 181-213.

Bezzi, S. I. \& P. Ibáñez. 2003. Estimaciones de la biomasa de la merluza (Merluccius hubbsi) entre 1994 y 1999 y características de la unidad de manejo norte $\left(34^{\circ}\right.$ a $\left.41^{\circ} \mathrm{S}\right)$. Frente Marítimo, 19: 47-56.

Bezzi, S. I. \& R. G. Perrotta. 1983. Determinación de la unidad del stock de la merluza (Merluccius hubbsi) del mar argentino a través del análisis de los caracteres merísticos y morfométricos. Contribución INIDEP, 429: 1-28.
Bezzi, S. I., M. Renzi, G. Irusta, B. Santos, L. S. Tringali, M. D. Ehrlich, F. Sánchez, S. B. García de la Rosa, M. Simonazzi \& R. Castrucci. 2004. Caracterización biológica y pesquera de la merluza (Merluccius hubbsi). Pp. 157-205. In: Sánchez, R. \& S. I. Bezzi (Eds.). El Mar Argentino y sus recursos pesqueros. Tomo 4: Los peces marinos de interés pesquero. Caracterización biológica y evaluación del estado de explotación. Mar del Plata, INIDEP, 359p.

Boltovskoy, E. 1981. Masas de agua en el Atlántico Sudoccidental. Pp. 227-236. In: Boltovskoy, D. (Ed.). Atlas del Zooplancton del Atlántico Sudoccidental y métodos de trabajo con el zooplankton marino. Mar del Plata, INIDEP, 936p.

Brown, D. R., E. Leonarduzzi \& L. Machinandiarena. 2004. Age, growth and mortality of hake larvae (Merluccius hubbsi) in the north Patagonian shelf. Scientia Marina, Barcelona, 68(2): 273-283.

Buratti, C. C. 2003. Microestructura de los otolitos sagittae de larvas y juveniles de Merluccius hubbsi (Marini, 1933): análisis comparativo entre las áreas de distribución bonaerense e norpatagónica. Unpublished Graduation Thesis, Universidad Nacional de Mar del Plata, Mar del Plata. 55p.

Cadwallader, P. L. 1978. Age, growth, and condition of the common river galaxias, Galaxia vulgaris Stokell, in the Glentui River, Cantebury. Fisheries Research Bulletin, 17: 15-20.

Campana, S. E. 1990. How reliable are growth back-calculations based on otoliths? Canadian Journal of Fisheries and Aquatic Sciences, 47: 2219-2227.

Castro, B. M., J. A. Lorenzetti, I. C. A. Silveira \& L. B. Miranda. 2006. Estrutura termohalina e circulação na região entre o Cabo de São Tomé (RJ) e o Chuí (RS). Pp. 11-120. In: RossiWongtschowski, C. L. D. B. \& L. S. P. Madureira. (Eds.). O ambiente oceanográfico da Plataforma Continental e do Talude na Região Sudeste-Sul do Brasil. São Paulo, EDUSP, 466p.

Christensen, J. M. 1964. Burning of otoliths, a technique for age determination of soles and other fish. Journal du Conseil Permanent International pour L'exploration de la Mer, 29: 73-81.

Ciechomski, J. D. 1967. Carácter del desove y fecundidad de la merluza argentina Merluccius hubbsi del sector bonaerense. Boletín del Instituto de Biología Marina, Mar del Plata, 13: 1-15.

Cotrina, C. P 1977. Interpretación de las escamas del besugo del Mar Argentino, Pagrus pagrus, en la determinación de edades. Physis, 36(92): 31-40.

Cousseau, M. B. \& R. G. Perrotta. 2004. Peces marinos de Argentina: biología, distribución, pesca. Mar del Plata, INIDEP, 167p.

Csirke, J. 1980. Introducción a la dinámica de poblaciones de peces. FAO Documentos Técnicos de Pesca, 192: 1-82.

Csirke, J. 1987. The patagonian fishery resources and the offshore fisheries in the South-West Atlantic. FAO Fishery Technical Paper, 286: 1-75.

David, G. S., P. A. S. Costa, E. B. Fagundes-Netto, L. R. Gaelzer \& A. C. Braga. 2005. Idade e crescimento do batata Lopholatilus villarii (Teleostei: Malacanthidae) na Região Central da ZEE, entre Salvador (BA) e o Cabo de São Tomé (RJ). Pp. 217-230. In: Costa, P. A. S., A. S. Martins \& G. Olavo, G. (Eds.). Pesca e potencias de exploração de recursos vivos na região central da Zona Econômica Exclusiva brasileira. Rio de Janeiro, Museu Nacional, 247p.

FAO, 1981. Methods of collecting and analyzing size and age data for fish stock assessment. FAO Fishery Circular, 736: 1-104.

Figueiredo, J. L. \& N. A. Menezes. 1978. Manual de peixes marinhos do Sudeste do Brasil II: Teleostei (1). São Paulo, Museu de Zoologia da USP, 110p.

Francis, R. I. C. C. 1990. Back-calculation of fish length: a critical 
review. Journal of Fish Biology, 36: 883-902.

Francis, R. I. C. C. 1995. The analysis of otolith data - a mathematician's perspective (what, precisely, is your model?). Pp. 81-95. In: Secor, D. H., J. M. Dean \& S. E. Campana (Eds.). Recent development in fish otolith research. Belle Baruch Library in Marine Science 19, 735p.

Gaggiotti, O. \& M. Renzi. 1990. El crecimiento alometrico en la merluza común (Merluccius hubbsi) y elección de un modelo de crecimiento apropiado. Frente Marítimo, 6: 7-24.

Gasalla, M. A. \& C. L. D. B. Rossi-Wongtschowski. 2004. Contribution of ecosystem analysis to investigating the effects of changes in fishing strategies in the South Brazil Bight coastal ecosystem. Ecological Modelling, 172 (2-4): 283-306.

Giussi, A. R., M. F. Villarino \& C. V. Dato. 1994. Distribución geográfica por grupos de edad de la merluza (Merluccius hubbsi) en el Mar Argentino entre los $35^{\circ}-47^{\circ} \mathrm{S}$ en el año 1983. Frente Marítimo, 15: 7-19.

Guerrero, R. A. \& A. R. Piola. 1997. Masas de agua en la plataforma continental. Pp. 107-118. In: Boschi, E. E. (Ed.). El Mar Argentino y sus recursos pesqueros. Tomo 1: Antecedentes históricos de las explotaciones en el mar y las características ambientales. Mar del Plata, INIDEP, 222p.

Gutiérrez, L. M; A. E. Ruiz \& M. E. Sendín. 1995. Identificación del stock de merluza (Merluccius hubbsi) en el área de Isla Escondida. Naturalia patagónica, Ciencias Biológicas, 3: 11-23.

Haimovici, M., A. O. Ávila-da-Silva \& C. L. D. B. RossiWongtschowski (Eds.). 2005. Prospecção pesqueira de espécies demersais com espinhel-de-fundo na Zona Econômica Exclusiva da Região Sudeste-Sul do Brasil. São Paulo, IOUSP / Série Documentos REVIZEE, 112p.

Haimovici, M., A. S. Martins \& E. R. L. Teixeira. 1993. Distribución, alimentación y observaciones sobre la reproducción de la merluza (Merluccius hubbsi) en el Sur de Brasil. Frente Marítimo, 14: 33-40.

Haimovici, M., C. L. D. B. Rossi-Wongtschowski, M. C. Cergole, L. S. P. Madureira, R. A. Bernardes \& A. O. Ávila-da-Silva. 2006. Recursos pesqueiros da Região Sudeste-Sul. Pp. 207234. In: MMA, 2006. Programa REVIZEE: avaliação do potencial sustentável de recursos vivos da Zona Econômica Exclusiva do Brasil - relatório executivo. Brasília, MMA, 279p.

Hile, R. 1970. Body-scale relation and calculation of growth in fishes. Transactions of the American Fisheries Society, 3: 468-474.

Honji, R. M., A. M. Vaz-dos-Santos \& C. L. D. B. RossiWongtschowski. 2006. Identification of the stages of ovarian maturation of the Argentine hake Merluccius hubbsi Marini, 1933 (Teleostei: Merlucciidae): advantages and disadvantages of the use of the macroscopic and microscopic scales. Neotropical Ichthyology, 4(3): 329-337.

Hyndes, G. A., N. R. Loneragan \& I. C. Potter. 1992. Influence of sectioning otoliths on marginal increment trends and age and growth estimates for the flathead Platycephalus speculator. Fishery Bulletin of the National Marine Fishery Service, 90(2): 276-284.

ICSEAF, 1983. Otolith interpretation guide of hake. International Commission for the Southeast Atlantic Fisheries, 1: 1-18.

Isaac-Nahum, V. J. 1990. The accuracy of some length-base methods for fish population studies. ICLARM Technical Report, 27: 1-81.

Kelly, C. J., P. L. Connoly \& J. J. Bracken. 1997. Age estimation, growth, maturity and distribution of the roundnose grenadier from the Rockall trough. Journal of Fish Biology, 50: 1-17.

King, M. 1995. Fisheries biology, assessment and management. Oxford, Fishing Books News, 346p.
Lessa, R., F. M. Santana \& P. Duarte-Neto. 2006. A critical appraisal of marginal increment analysis for assessing temporal periodicity in band formation among tropical sharks. Environmental Biology of Fishes, 77(3-4): 309-315.

Lombarte, A. \& J. Lleonart. 1993. Otolith size changes related with body growth, habitat depth and temperature. Environmental Biology of Fishes, 37: 297-306.

Lorenzo, M. I. 2003. Crecimiento y mortalidad de la merluza en la Zona Común de Pesca Argentino-Uruguaya. Frente Marítimo, 19: $37-46$

Macchi, G. J., M. Pájaro, M. I. Militelli, N. Radovani \& L. Rivas. 2006. Influence of size, age and maternal condition on the oocyte dry weight of Argentine hake (Merluccius hubbsi). Fisheries Research, 80: 345-349.

Matsuura, S. 1961. Age and growth of flatfish, ganzo-birame, Pseudorhombus cinnamoneus (Temminck et Schlegel). Records of Oceanographic Works in Japan, 5: 103-110.

Menezes, N. A., P. A. Buckup, J. L. Figueiredo \& R. L. Moura (Eds.) 2003. Catálogo das espécies de peixes marinhos do Brasil. São Paulo, Museu de Zoologia da USP, 160p.

Mio, S. 1961. Age and growth of red sea bream, Evynnis japonica Tanaka. Records of Oceanographic Works in Japan, 5: 95-101.

Munro, G. R. \& D. Pauly. 1983. A simple method for comparing the growth of fishes and invertebrates. Fishbyte, 1(1): 5-6.

Newberger, T. A. \& E. D. Houde. 1995. Population biology of bay anchovy Anchoa mitchilli in the mid Chesapeake Bay. Marine Ecology Progress Series, 116: 25-37.

Norbis, W., M. I. Lorenzo \& G. J. Torres. 1999. Intra-annual growth variations of young-of-the-year hake (Merluccius hubbsi) of the Uruguayan continental shelf based on otoliths analysis. Fisheries Research, 44: 129-137.

Odemar, M. W. \& J. M. Silvosa. 1971. Abundancia, distribución y biología de la merluza del sector Bonaerense en Primavera. Proyecto de Desarrollo Pesquero Serie Informes Técnicos, 31: 1-27.

Otero, H. O. 1977. Edad y crecimiento de la merluza (Merluccius merluccius hubbsi). Physis, 36(92): 41-58.

Perez, J. A. A. \& P. R. Pezzutto. 2006. A pesca de arrasto de talude do Sudeste e Sul do Brasil: tendências da frota nacional entre 2001 e 2003. Boletim do Instituto de Pesca, São Paulo, 32(2): 127-150.

Perez, J. A. A., R. Warlich, P. R. Pezzutto, P. R. Schwingel, F. R. A. Lopes \& M. Rodrigues-Ribeiro. 2003. Deep-sea fishery off Southern Brazil: recent trends of the Brazilian Fishing Industry. Journal of Northwest Atlantic Fishery Science., 31: 1-18.

Perrotta, R. G. \& F. Sánchez. 1992. Una vez más acerca de la identificación de las poblaciones de merluza (Merluccius hubbsi) en la Plataforma Argentino-Uruguaya. Frente Marítimo, 12: 3946.

Piola, A. R. \& A. L. Rivas. 1997. Corrientes en la plataforma continental. Pp. 119-132. In: Boschi, E. E. (ed.). El Mar Argentino y sus recursos pesqueros. Tomo 1: Antecedentes históricos de las explotaciones en el mar y las características ambientales. Mar del Plata, INIDEP, 222p.

Podestá, G. P. 1990. Migratory pattern of Argentine hake Merluccius hubbsi and oceanic processes in the Southwestern Atlantic Ocean. Fishery Bulletin, 88: 167-177.

Polat, N. \& A. Gümü . 1996. Ageing of whiting (Merlangius merlangus euxinus, Nord., 1840) based on broken and burnt otolith. Fisheries Research, 28: 231-236.

Prenski, L. B. \& V. Angelescu. 1993. Ecología trófica de la merluza común (Merluccius hubbsi) del Mar Argentino Parte 3: consu- 
mo anual de alimento a nivel poblacional y su relación con la explotación de las pesquerías multiespecíficas. INIDEP Documento Científico, 1: 1-119.

Prenski, L. B. \& S. I. Bezzi. 1991. Interdependencia de la estructura de talla de la merluza (Merluccius hubbsi) y los factores abióticos y bióticos. Estimación cuantitativa del canibalismo en la Zona Común de Pesca Argentino-Uruguaya. Frente Marítimo, 8: 7-28.

Renzi, M. \& M. Pérez. 1992. Un criterio para la determinación de la edad en juveniles de merluza (Merluccius hubbsi) mediante la lectura de otolitos. Frente Marítimo, 11: 15-31.

Renzi, M., B. Santos \& M. Simonazzi. 1999. Edad, crecimiento y estructura poblacional de merluza. Pp. 107-110. In: INIDEP/ JICA. Avances en métodos y tecnología aplicados a la investigación pesquera. Seminario final del Proyecto INIDEPJICA sobre evaluación y monitoreo de recursos pesqueros 1994 1999. Mar del Plata, INIDEP, 249p.

Rey, M. \& G. Arena (Eds.) 1999. Merluza (Merluccius hubbsi): estudios comparativos realizados dentro de la Zona Común de Pesca Argentina-Uruguaya en el marco del plan de investigación pesquera (proyecto URU/92/003). Montevideo, INAPE/ PNUD, 211p.

Rey, M., S. I. Bezzi, G. Verazay \& J. O. Stemmer. 1996. Áreas de veda para la protección de los juveniles de merluza (Merluccius hubbsi) en la Zona Común de Pesca, hasta diciembre de 1993. Frente Marítimo, 16: 7-27.

Rey, M., J. Cascudo \& O. Defeo. 1987. Evaluación preliminar de un recurso compartido en base al análisis de cohortes (Pope, 1972) en la Zona Común de Pesca Argentino-Uruguaya. Publicaciones de la Comisión Técnica Mixta del Frente Marítimo, 3: 53-57.

Rojo, A. L. \& J. M. Silvosa. 1969. Investigación sobre la merluza (Merluccius merluccius hubbsi) del sector bonaerense (Campaña "Merluza 68-1" - 20 Nov. - 5. Dic. 1968). Proyecto de Desarrollo Pesquero Serie Informes Técnicos, 17: 1-34.

Rossi-Wongtschowski, C. L. D. B. \& L. S. P. Madureira (Eds.). 2006. O ambiente oceanográfico da Plataforma Continental e do Talude na Região Sudeste-Sul do Brasil. São Paulo, EDUSP, 466 .

Rossi-Wongtschowski, C. L. D. B. \& E. T. Paes. 1993. Padrões espaciais e temporais da comunidade de peixes demersais do litoral norte do Estado de São Paulo - Ubatuba, Brasil. Publicação Especial do Instituto Oceanográfico, S Paulo, 10: 169-188.

Ruarte, C. O. 1997. Relaciones del tamaño y peso del otolito con la longitud y edad del pez en la merluza (Merluccius hubbsi) para tres zonas del Mar Argentino. Unpublished Graduation Thesis, Universidad Nacional de Mar del Plata, Mar del Plata. 38p.

Ruiz, A. E. \& R. R. Fondacaro. 1997. Diet of hake (Merluccius hubbsi Marini) in a spawning and nursery area within Patagonian shelf waters. Fisheries Research, 30: 157-160.

Sabatini, M. E. 2004. Características ambientales, reproducción y alimentación de la merluza (Merluccius hubbsi) y la anchoita (Engraulis anchoita) en su habitat reproductivo patagónico: síntesis y perspectivas. Revista de Investigación y Desarrollo Pesquero, 16: 5-25.

Sánchez, F. \& S. B. García de la Rosa. 1999. Alimentación de Merluccius hubbsi e impacto del canibalismo en la región comprendida entre $34^{\circ} 50^{\prime}-47^{\circ} \mathrm{S}$ del Atlântico Sudoccidental. Revista de Investigación y Desarrollo Pesquero, 12: 77-93.

Sardella, N. H. \& J. T. Timi. 2004. Parasites of Argentine hake in the Argentine Sea: population and infracommunity structure as evidence for host stock discrimination. Journal of Fish Biology, 65: 1472-1488.

Secor, D. H., J. M. Dean \& E. H. Laban. 1991. Manual for otolith and preparation for microstructural examination. Tech. Publ. 1991-01. Belle Baruch Institute for Biology and Coastal Research, 85p.

Seeliger, U., C. Odebrecht \& J. P. Castello. 1998. Os ecossistemas costeiro e marinho do extremo sul do Brasil. Rio Grande, Ecoscientia, 326p.

Sparre, P., Venema, S. C. 1998. Introduction to tropical fish stock assessment. FAO Fishery Technical Paper, 306/1(2): 1-407.

Tanaka, K., Y. Mugiya \& J. Yamada. 1981. Effects of photoperiod and feeding on the daily growth patterns in otoliths of juvenile Tilapia nillotica. Fishery Bulletin of the National Marine Fishery Service, 79: 459-465.

Torres, G. J., W. Norbis \& M. I. Lorenzo. 1996. Variations in the measures of argentine hake (Merluccius hubbsi) rings otoliths during their first-year: evidence for stocks separation? Scientia Marina, Barcelona, 60(2-3): 331-338.

Valentini, H. \& P. R. Pezzutto. 2006. Análise das principais pescarias comerciais da Região Sudeste/Sul do Brasil com base na produção controlada do período 1986 - 2004. São Paulo, IOUSP / Série Documentos REVIZEE, 51p.

Vaz-dos-Santos, A. M. 2002. Idade e crescimento da merluza Merluccius hubbsi Marini, 1933 (Teleostei: Merlucciidae) na Zona Econômica Exclusiva entre o Cabo de São Tomé (RJ) e o Chuí (RS), Brasil. Unpublished M.Sc. Dissertation, Instituto Oceanográfico da Universidade de São Paulo, São Paulo. 190p.

Vaz-dos-Santos, A. M. 2005. La pesca marítima en el Sudeste y Sur del Brasil. Revista Ceciliana 16(23): 101-113.

Vaz-dos-Santos, A. M., R. M. Honji \& C. L. D. B. RossiWongtschowski. 2005. Comprimento e idade de primeira maturação gonadal de fêmeas de merluza Merluccius hubbsi Marini, 1933 na Região Sudeste-Sul do Brasil. Boletim do Instituto de Pesca, São Paulo, 31(2): 109-117.

Vaz-dos-Santos, A. M. \& C. L. D. B. Rossi-Wongtschowski. 2005. Merluccius hubbsi Marini, 1933. Pp. 88-93. In: Cergole, M. C., A. O. Ávila-da-Silva \& C. L. D. B. Rossi-Wongtschowski (Eds.). Análise das principais pescarias comerciais da Região SudesteSul do Brasil: dinâmica populacional das espécies em explotação. São Paulo, IOUSP / Série Documentos REVIZEE, 176p.

Vaz-dos-Santos, A. M., C. L. D. B. Rossi-Wongtschowski \& J. L. Figueiredo. 2006. Recursos pesqueiros compartilhados entre Brasil, Uruguai e Argentina: a problemática de Merluccius hubbsi, Engraulis anchoita, Umbrina canosai e Illex argentinus. Rio de Janeiro, II SEGAP: 1-10.

Vazzoler, A. E. A. de M. 1996. Biologia da reprodução de peixes teleósteos: teoria e prática. Maringá, EDUEM, 169p.

Villarino, M. F. \& A. Giussi. 1992. Distribución geográfica por grupo de edad de la merluza común (Merluccius hubbsi) durante 1982 en el Mar Argentino entre los $35^{\circ}-47^{\circ} \mathrm{S}$. Boletín del Instituto Español de Oceanografía, 8 (2): 339-353.

Walters, C. J. \& S. J. D. Martell. 2004. Fisheries ecology and management. Princeton, Princeton University Press, 399p.

Weatherley, A. H. \& H. S. Gill. 1987. The biology of fish growth. London, Academic Press, 443p.

Whitney, R. R. \& K. Carlander. 1956. Interpretation of body-scale regression for computing body lenght of fish. Journal of Wildlife Management, 20(1): 21-27.

Zar, J. H. 1999. Biostatistical analysis. $4^{\text {th }}$ Ed. New Jersey, Prentice Hall, 663p.

Zavala-Camin, L. A. 1996. Introdução aos estudos sobre alimentação natural em peixes. Maringá, EDUEM, 129p.

Submitted April 2007 Accepted August 2007 